\title{
PENGARUH PEMBANGUNAN PELABUHAN UMUM MOBONGO TERHADAP LALU LINTAS DI KABUPATEN MINAHASA SELATAN
}

\author{
Widorisnomo \\ Dosen Program Diploma IV \\ Lalu Lintas Angkutan dan Jalan \\ Sekolah Tinggi Transportasi \\ Darat \\ Jl. Raya Setu KM. 3,5 Cibuntu \\ Cibitung Bekasi \\ Tlp: (021) 8254640, 82608995 \\ Fax: (07.1) 87.608995
}

\author{
Jopie Jehosua \\ Dosen Program Diploma IV \\ Lalu Lintas Angkutan dan Jalan \\ Sekolah Tinggi Transportasi Darat \\ Jl. Raya Setu KM. 3,5 Cibuntu \\ Cibitung Bekasi \\ Tlp: (021) 8254640, 82608995 \\ Fax: (021) 82608995
}

\author{
Novia Iswara Pratiwi \\ Taruna Program D-IV \\ Sekolah Tinggi Transportasi Darat \\ Jl. Raya Setu KM. 3,5 Cibuntu \\ Cibitung Bekasi \\ Tlp: (021) 8254640, 82608995
}

Fax: (021) 82608995

noviaiswarapratiwi@ rocketmail.com

\begin{abstract}
In order to facilitate the distribution of natural products that exist in the South Minahasa District then carried out the construction of the port where the traffic generation and attraction not only of South Minahasa district itself but also from neighboring districts. This of course led to the addition of the volume lntas in South Minahasa regency where these roads are Jalan Trans Sulawesi, which is the pathway connecting the city and district in the island of Sulawesi. The purpose of this study was to determine the resurrection and pull large Mobongo Public Ports and its impact on traffic in the South Minahasa District. This study used data collected from the study location in 2014, which is planned to be dioprasikan port plan in 2016 and conducted research until 2021 using regression analysis. The analysis showed seizure caused 422 smp / hour and traffic management has not been able to deal with the problems posed so needs widening at Jalan Trans Sulawesi and restriction of heavy vehicle.
\end{abstract}

Keywords: Trans Sulawesi, Ports, Influence Development, Traffic Performance

\begin{abstract}
ABSTRAKSI
Guna memudahkan distribusi hasil alam yang ada di Kabupaten Minahasa Selatan maka dilakukan pembangunan pelabuhan dimanabangkitan dan tarikan lalu lintas tidak hanya dari wilayah Kabupaten Minahasa Selatan itu sendiri tetapi juga dari kabupaten-kabupaten sekitar. Hal ini tentu saja menyebabkan penambahan volume lalu Intas di Kabupaten Minahasa Selatan dimana ruas jalan tersebut merupakan Jalan Trans Sulawesi yang merupakan jalur penghubung kota maupun kabupaten yang ada di Pulau Sulawesi. Tujuan penelitian ini adalah untuk mengetahui besar bangkitan dan tarikan Pelabuhan Umum Mobongo dan pengaruhnya terhadap lalu lintas di Kabupaten Minahasa Selatan. Penelitian ini menggunakan data yang dikumpulkan dari lokasi kajian pada tahun 2014, dimana rencana pelabuhan direncanakan akan dioprasikan pada tahun 2016 dan penelitian dilakukan hingga tahun 2021 dengan menggunakan analisis regresi. Hasil analisis menunjukkan bangkitan yang ditimbulkan $422 \mathrm{smp} / \mathrm{jam}$ dan manajemen lalu lintas belum mampu menangani permasalahan yang ditimbulkan sehingga perlu dilakukan pelebaran di Jalan Trans Sulawesi dan melakukan pembatasan kendaraan berat.
\end{abstract}

Kata kunci : Trans Sulawesi, Pelabuhan, Pengaruh Pembangunan, Kinerja Lalu Lintas

\section{PENDAHULUAN}

Kabupaten Minahasa Selatan merupakan jalur strategis karena dilalui oleh jalan Trans Sulawesi yang merupakan jalan nasional yang menjadi jalan penghubung kota kota yang berada di Sulawesi Utara dengan kota - kota yang berada di Sulawesi Selatan. Hal 
ini mengakibatkan Kabupaten Minahasa Selatan terus mengalami pertumbuhan, guna mengantisipasi pertumbuhan telah dibuat kebijaksanaan penerapan Kabupaten Minahasa Selatan, sebagaimana yang telah dituangkan dalam rencana tata ruang wilayah (RTRW) Kabupaten Minahasa Selatan tahun 2014 - 2034. Sebagai upaya peningkatan kuantitas, kualitas dan pengelolaan prasarana dan sarana serta utilitas yang mendukung agribisnis maka dilakukan peningkatan peran pelabuhan umum Mobongo di Kecamatan Amurang Barat Kelurahan Kawangkoan Bawah dengan menambah jumlah dermaga dan melakukan perluasan kawasan pelabuhan. Dimana dalam rencana pengembanganya Pelabuhan Umum Mobongo akan dijadikan sebagai pelabuhan pengumpul, yang nantinya akan membangkitkan perjalanan bukan hanya dari dalam Kabupaten Minahasa Selatan saja melainkan akan membangkitkan perjalanan dari kabupaten - kabupaten sekitar Hal tersebut dapat menimbulkan dampak negatif bagi kinerja jaringan jalan yaitu menurunnya tingkat pelayanan (level of service/LOS) jaringan jalan di sekitar penerapan Pelabuhan Umum Mobongo.

\section{TINJAUAN PUSTAKA}

\section{Pelabuhan}

Pelabuhan adalah fasilitas di ujung samudra, sungai atau danau untuk menerima kapal dan memindahkan penumpang ataupun barang ke dalamnya. Menurut Peraturan Pemerintah no 69 tahun 2001 tentang Kepelabuhanan, yang dimaksud pelabuhan adalah tempat yang terdiri dari daratan dan perairan disekitarnya dengan batas-batas tertentu sebagai tempat kegiatan pemeriintahan dan kegiatan ekonomi dipergunakan sebagai tempat kapal bersandar, berlabuh, naik turun penumpang dan atau bongkar muat barang yang dilengkapi dengan fasilitas keselamatan pelayaran dan kegiatan penunjang pelabuhan serta sebagai tempat perpindahan intra dan antar moda transportasi.

Bambang Triatmodjo ( 2007 ) dalam bukunya mengatakan bahwa pelabuhan merupakan daerah perairan yang terlindung terhadap gelombang yang dilengkapi dengan fasilitas terminal laut meliputi dermaga dimana kapal dapat bertambat untuk bongkar dan muat barang, kran - kran untuk muat dan bongkar barang, gudang laut ( transito ) dan tempat penyimpanan dimana kapal yang lebih lama selama menunggu pengiriman ke daerah tujuan atau pengapalan.

\section{Analisis Dampak Lalu Lintas}

Dalam UU Nomor 22 Tahun 2009 tentang Lalu Lintas dan Angkutan Jalan, analisis dampak lalu lintas dijelaskan pada pasal 99 ayat 1 yang isinya "Setiap rencana pembangunan pusat kegiatan, permukiman, dan infrastruktur yang akan menimbulkan 
gangguan Keamanan, Keselamatan, Ketertiban, dan Kelancaran Lalu Lintas dan Angkutan Jalan wajib dilakukan analisis dampak Lalu Lintas". Selanjutnya pada pasal 99 ayat 2 disebutkan "Analisis dampak Lalu Lintas sebagaimana dimaksud pada ayat (1) sekurang-kurangnya memuat: (a) analisis bangkitan dan tarikan Lalu Lintas dan Angkutan Jalan; (b) simulasi kinerja Lalu Lintas tanpa dan dengan adanya pengembangan; (c) rekomendasi dan rencana implementasi penanganan dampak; (d) tanggung jawab Pemerintah dan pengembang atau pembangun dalam penanganan dampak; dan (e) rencana pemantauan dan evaluasi”.

\begin{tabular}{ll}
\hline Peruntukan Lahan & Ukuran Minimal Kawasan Yang Wajib Andalalin \\
\hline Pemukiman & $50 \mathrm{Unit}$ \\
Apartemen & $50 \mathrm{Unit}$ \\
Perkantoran & $1.000 \mathrm{~m}^{2}$ luas lantai bangunan \\
Pusat Perbelanjaan & $500 \mathrm{~m}^{2}$ luas lantai bangunan \\
Hotel / Penginapan & $50 \mathrm{Kamar}$ \\
Rumah Sakit & 50 Tempat Tidur \\
Klinik Bersama & 10 Ruang Praktek Dokter \\
Sekolah / Universitas & 500 Siswa \\
Tempat Kursus & Bangunan dengan kapasitas 50 siswa / waktu \\
Industry/ Pergudangan & 2.500 m²luas lantai bangunan \\
Restaurant & 100 tempat dududk \\
Tempat Pertemuan & 100 tamu \\
Terminal & Wajib \\
Pelabuhan & Wajib \\
SPBU & 4 Slang Pompa \\
Bengkel & 2.000 m² luas lantai bangunan \\
Drive - Though, Bank & Wajib \\
\hline Sumber : Pedoman Teknis & Andalalin Departemen Perhubungan
\end{tabular}

\section{Kriteria Dampak Lalu Lintas}

\begin{tabular}{|c|c|c|c|}
\hline Lokasi & $\begin{array}{l}\text { Elemen Dampak } \\
\text { Lalu Lintas Jalan }\end{array}$ & $\begin{array}{l}\text { Indikator Dampak Lalu } \\
\text { Lintas Jalan }\end{array}$ & Metode Pengukuran \\
\hline \multirow[t]{4}{*}{ Ruas Jalan } & Lalu Lintas & Derajat Kejenuhan & Analisis Kapasitas Ruas Jalan \\
\hline & \multirow[t]{2}{*}{ Kendaraan } & Kecepatan Lalu Lintas di & Analisis Kecepatan Arus Bebas \\
\hline & & Ruas Jalan (Km/jam) & $\begin{array}{l}\text { Analisis Perilaaku Lalu Lintas untuk } \\
\text { Ruas Jalan }\end{array}$ \\
\hline & $\begin{array}{l}\text { Lalu Lintas Pejalan } \\
\text { Kaki }\end{array}$ & Tingkat Pelayanan & Analisis Kecepatan Pejalan Kaki \\
\hline Persimpangan & Lalu lintas & Derajat Kejenuhan & Analisis Kapasitas Untuk \\
\hline \multirow[t]{11}{*}{ Jalan } & Kendaraan & Tundaaan (dtk/smp) & Persimpangan Bersinyal dan/atau \\
\hline & & & Persimpangan tak bersinyal \\
\hline & & & Analisis Tundaan untuk \\
\hline & & & Persimpangan Bersinyal dan/atau \\
\hline & & & Persimpangan tak bersinyal \\
\hline & & & Analisis Perilaku Lalu Lintas Untuk \\
\hline & & & Persimpangan Bersinyal dan/atau \\
\hline & & & Persimpangan tak bersinyal \\
\hline & \multirow{3}{*}{$\begin{array}{l}\text { Lalu Lintas Pejalan } \\
\text { Kaki }\end{array}$} & \multirow[t]{3}{*}{ Tingkat Pelayanan } & Analisis Tundaan Pejalan Kaki di \\
\hline & & & Persimpangan Bersinyal dan/atau \\
\hline & & & Persimpangan tak bersinyal \\
\hline
\end{tabular}

Sumber : Pedoman Andalalin PU

\section{Manajemen dan Rekayasa lalu Lintas}

Pasal 3 UU Nomor 22 tahun 2009 tentang Lalu Lintas dan Angkutan Jalan menyebutkan "Lalu lintas dan Angkutan Jalan diselenggarakan dengan tujuan 
mewujudkan pelayanan lalu lintas dan angkutan jalan yang aman, selamat tertib lancar dan terpadu dengan moda angkutan lain untuk mendorong perekonomian nasional, memajukan kesejahteraan umum, memperkukuh persatuan dan kesatuan bangsa, serta mampu menjunjung tinggi martabat bangsa;”. Hal ini mengisyaratkan bahwa salah satu tujuan penyelenggaraan transportasi jalan adalah untuk mewujudkan transportasi yang tertib dan lancar adalah dengan melakukan manajemen rekayasa lalu lintas.

\section{Kapasitas Jalan}

Kapasitas jalan perkotaan dapat dihitung dengan menggunakan rumus :

$$
C=C_{o} \times F C_{w} \times F C_{s p} \times F C_{S f} \times F C_{c S}
$$

Dimana :

$\mathrm{C}=\operatorname{kapasitas}(\mathrm{smp} / \mathrm{jam})$

$\mathrm{C}_{\mathrm{o}}=$ kapasitas dasar untuk kondisi tertentu atau ideal

$\mathrm{FC}_{\mathrm{w}}=$ factor penyesuaian lebar lajur lalu lintas

$\mathrm{FC}_{\mathrm{sp}}=$ factor penyesuaian pemisahan arah

$\mathrm{FC}_{\text {sf }}=$ factor penyesuaian dengan bahu jalan

$\mathrm{FC}_{\mathrm{cs}}=$ factor penyesuaian kapasitas untuk ukuran kota

\section{Fasilitas Pejalan Kaki}

$$
W_{d}=\frac{P}{35}+n
$$

Sumber : Ditjen Perhubungan Darat, 1996

Dimana :

$\mathrm{W}=$ lebar trotoar yang dibutuhkan

$\mathrm{P} \quad=$ volume rata - rata pejalan kaki per menit

$35=$ arus pejalan kaki maksimum per meter lebar menit

$\mathrm{N}=$ untuk daerah pertokoan dengan kios $\quad=1,5 \mathrm{~m}$

Untuk daerah pertokoan tanpa kios $\quad=1,0 \mathrm{~m}$

Untuk semua jalan yang lain $\quad=0,5 \mathrm{~m}$

\section{Fasilitas parkir}

\begin{tabular}{ll}
\hline Jenis Kendaraan & Satuan Ruang Parkir ( m2 ) \\
\hline Mobil penumpang golongan I & $2,30 \times 5,00$ \\
Mobil penumpang golongan II & $2,50 \times 5,00$ \\
Mobil Penumpang golongan III & $3,40 \times 5,00$ \\
Bus / Truk & $3,40 \times 12,5$ \\
Sepeda Motor & $0,75 \times 2,00$ \\
\hline Sumber : Keputusan Dirjenhub Darat No.272,1996
\end{tabular}




\section{Metode Pertumbuhan Rata - Rata}

$$
P t=P o(i+1)^{n}
$$

Dimana :

$\begin{array}{lll}\mathrm{Pt} & = & \text { jumlah kendaraan tahun target } \\ \mathrm{Po} & = & \text { jumlah kendaraan tahun awal perhitungan } \\ \mathrm{I} & = & \text { tingkat pertumbuhan rata }- \text { rata } \\ \mathrm{n} & = & \text { jumlah tahun (tahun prediksi dikurangi tahun dasar) }\end{array}$

\section{Analisis Regresi}

$$
Y=a+b x
$$

Dimana :

$$
\begin{aligned}
& =\text { konstanta } \\
& =\text { koofisisen regresi }
\end{aligned}
$$

\section{ANALISIS DAN PEMBAHASAN}

\section{Pengumpulan Data}

\begin{tabular}{ll}
\hline \multicolumn{1}{c}{ Data Sekunder } & \multicolumn{1}{c}{ Data Primer } \\
\hline Peta administrasi & Kapasitas perjalanan \\
Peta jaringan jalan & Volume lalu lintas ruas dan simpang \\
Data pembebanan jaringan jalan Kabupaten & Asal tujuan perjalanan \\
Minahasa Selatan & Kecepatan perjalanan \\
Site Plan pembangunan Pelabuhan Mobonggo & Data Pejalan kaki \\
Statistik daerah Studi & Data Angkutan Umum yang melewati Kawasan \\
Potensi angkutan barang & Pelabuhan \\
\hline
\end{tabular}

\section{Analisis Data}

Analisis kondisi eksisting menyajikan data survai primer yang telah dilakukan.

Dalam kondisi eksisting V/C rasio ruas jalan di Kabupaten Minahasa Selatan masih dalam keadaaan stabil dimana V/C rasio tertinggi senilai 0,55 pada ruas jalan Trans Sulawesi 1 dengan nomor link 3081.

Tabel 1 Ruas Jalan Dengan Kinerja Terburuk Pada Tahun 2014

\begin{tabular}{ccccccc}
\hline \multirow{2}{*}{ Kode Link } & Nama Jalan & Volume & Kapasitas & V/C Ratio & Kecepatan & Kinerja \\
\hline 3034 & Jl. Pasar 17 & 324 & 673 & 0,48 & 36,0 & B \\
3041 & Jl. Trans Sulawesi 1 & 748 & 1305 & 0,57 & 40,2 & B \\
3043 & Jl. Trans Sulawesi 1 & 609 & 1266 & 0,48 & 45,1 & B \\
3053 & Jl. Trans Sulawesi 1 & 559 & 1227 & 0,46 & 45,0 & B \\
3061 & Jl. Trans Sulawesi 1 & 593 & 1266 & 0,47 & 45,0 & B \\
3063 & Jl. Trans Sulawesi 1 & 561 & 1266 & 0,44 & 45,1 & B \\
3071 & J1. Trans Sulawesi 1 & 595 & 1226 & 0,49 & 45,1 & B \\
3081 & Jl. Trans Sulawesi 1 & 664 & 1227 & 0,54 & 45,3 & B \\
3111 & Jl. Trans Sulawesi 2 & 495 & 1090 & 0,45 & 45,0 & B \\
\hline
\end{tabular}

Sumber : hasil analisa 


\section{Analisa Kondisi Pengoprasian Pelabuhan}

Pada penelitian ini pelabuhan direncanakan akan beroprasi pada tahun 2016, oleh karena itu pada tahun 2016 dilakukan permbebanan pada kondisi tanpa adanya pembangunan dan dengan adanya pembangunan pelabuhan dan terlihat bahwa beberapa ruas jalan mengalami penurunan kinerja jalan. Pada perkiraan jumlah volume lalu lintas pada tahun 2016 tanpa adanya pembangunan pelabuhan menggunakan rumus coumpounding dengan data jumlah volume lalu lintas hasil survai tahun 2014 sebagai kondisi eksisiting dan menggunakan tingkat pertumbuhan rata - rata volume lalu lintas di Kabupaten Minahasa Selatan sebesar 8,16\%. Untuk ruas jalan baru sebagai akses keluar masuk dari dan menuju pelabuhan yaitu ruas jalan Trans Sulawesi 1 dengan kode link 3141, 3143, 3151 dan 3153. Pada tahun 2016 selain pelabuhan Umum Mobongo yang akan beroprasi, direncanakan pada tahun tersebut Pelabuhan Penyebrangan Amurang yang terletak bersebelahan dengan Pelabuhan Umum Mobongo juga akan beroprasi. Oleh karena itu, pada pembebanan yang dilakukan pada tahun 2016, terdapat 2 pusat bangkitan dan tarikan baru.

Tabel 2 Ruas Jalan Yang Mengalami Penurunan Kinerja Lalu Lintas Tahun 2016

\begin{tabular}{|c|c|c|c|c|c|c|c|c|c|c|}
\hline \multirow{2}{*}{$\begin{array}{l}\text { Kode } \\
\text { Link }\end{array}$} & \multirow[b]{2}{*}{ Nama Jalan } & \multirow[b]{2}{*}{ Kapasitas } & \multicolumn{4}{|c|}{ Tanpa Pembangunan } & \multicolumn{4}{|c|}{ Dengan Pembangunan } \\
\hline & & & $\mathbf{V}$ & $\begin{array}{c}\text { V/C } \\
\text { Rasio }\end{array}$ & $\mathbf{S}$ & Kinerja & $\mathbf{V}$ & $\begin{array}{c}\text { V/C } \\
\text { Rasio }\end{array}$ & $\mathbf{S}$ & Kinerja \\
\hline 3021 & Jl. Trans Sulawesi 1 & 1292 & 536 & 0,41 & 42,0 & B & 621 & 0,48 & 37,0 & $\mathrm{C}$ \\
\hline 3052 & Jl. Trans Sulawesi 1 & 673 & 295 & 0,44 & 45,0 & $\mathrm{~B}$ & 308 & 0,46 & 30,0 & $\mathrm{C}$ \\
\hline 3113 & Jl. Trans Sulawesi 2 & 1090 & 447 & 0,41 & 45,0 & $\mathrm{~B}$ & 485 & 0,44 & 37,0 & $\mathrm{C}$ \\
\hline 3132 & Jl. Trans Sulawesi 2 & 673 & 320 & 0,48 & 36,0 & B & 330 & 0,49 & 30,0 & $\mathrm{C}$ \\
\hline 3141 & Jl. Trans Sulawesi 1 & 1227 & - & - & & - & 797 & 0,65 & 44,6 & $\mathrm{C}$ \\
\hline 3143 & Jl. Trans Sulawesi 1 & 1227 & - & - & & - & 772 & 0,63 & 45,0 & $\mathrm{C}$ \\
\hline 3151 & Jl. Trans Sulawesi 1 & 1227 & - & - & & - & 831 & 0,68 & 38,6 & $\mathrm{C}$ \\
\hline 3153 & Jl. Trans Sulawesi 1 & 1292 & - & - & & - & 775 & 0,60 & 37,6 & $\mathrm{C}$ \\
\hline
\end{tabular}

\section{Analisa Kondisi Yang Akan Datang}

Analisa kondisi yang akan datang direncanakan dilakukan pada 5 tahun pasca pengoprasian yaitu pada tahun 2021. Untuk memperkirakan jumlah perjalanan yang terjadi pada tahun 2021 digunakan persamaan regresi sebagai berikut :

$$
Y=-164,178+0,008 X 2+0,01 X 3+0,004 X 4+e
$$

Dimana :

$\mathrm{Y}=$ Jumlah Perjalanan

$\mathrm{X} 2=$ Kepemilikan Kendaraan

$\mathrm{X} 3=\mathrm{PDRB}$ daerah

$\mathrm{X} 4=$ Produktivitas daerah 
Tabel 3 Ruas Jalan Yang Mengalami Penurunan Kinerja Lalu Lintas Tahun 2021

\begin{tabular}{|c|c|c|c|c|c|c|c|c|c|c|}
\hline \multirow{2}{*}{$\begin{array}{l}\text { Kode } \\
\text { Link }\end{array}$} & \multirow[b]{2}{*}{ Nama Jalan } & \multirow[b]{2}{*}{ Kapasitas } & \multicolumn{4}{|c|}{ Tanpa Pembangunan } & \multicolumn{4}{|c|}{ Dengan Pembangunan } \\
\hline & & & $\mathbf{V}$ & $\begin{array}{c}\text { V/C } \\
\text { Rasio }\end{array}$ & $\mathbf{S}$ & Kinerja & $\mathbf{V}$ & $\begin{array}{c}\text { V/C } \\
\text { Rasio }\end{array}$ & $\mathbf{S}$ & Kinerja \\
\hline 3021 & Jl. Trans Sulawesi 1 & 1292 & 778 & 0,60 & 36,0 & $\mathrm{C}$ & 1200 & 0,93 & 30,0 & $\mathrm{D}$ \\
\hline 3031 & Jl. Trans Sulawesi 1 & 1292 & 953 & 0,74 & 34,0 & $\mathrm{C}$ & 1266 & 0,98 & 32,0 & $\mathrm{E}$ \\
\hline 3033 & Jl. Trans Sulawesi 1 & 1305 & 682 & 0,52 & 35,1 & $\mathrm{C}$ & 1000 & 0,77 & 33,4 & $\mathrm{D}$ \\
\hline 3043 & Jl. Trans Sulawesi 1 & 1266 & 1058 & 0,84 & 35,0 & $\mathrm{C}$ & 1220 & 0,96 & 28,0 & $\mathrm{E}$ \\
\hline 3051 & Jl. Trans Sulawesi 1 & 1266 & 911 & 0,72 & 33,0 & $\mathrm{C}$ & 1184 & 0,94 & 30,0 & $\mathrm{D}$ \\
\hline 3053 & Jl. Trans Sulawesi 1 & 1227 & 970 & 0,79 & 28,1 & $\mathrm{C}$ & 1160 & 0,95 & 28,1 & $\mathrm{E}$ \\
\hline 3061 & Jl. Trans Sulawesi 1 & 1266 & 1035 & 0,82 & 37,0 & $\mathrm{C}$ & 1278 & 1,01 & 28,1 & $\mathrm{~F}$ \\
\hline 3063 & Jl. Trans Sulawesi 1 & 1227 & 972 & 0,77 & 35,0 & $\mathrm{C}$ & 1162 & 0,95 & 28,0 & $\mathrm{E}$ \\
\hline 3071 & Jl. Trans Sulawesi 1 & 1292 & 1041 & 0,85 & 32,3 & $\mathrm{C}$ & 1275 & 0,99 & 30,4 & $\mathrm{E}$ \\
\hline 3073 & Jl. Trans Sulawesi 1 & 1226 & 887 & 0,72 & 37,3 & $\mathrm{C}$ & 1098 & 0,90 & 33,0 & $\mathrm{D}$ \\
\hline 3111 & Jl. Trans Sulawesi 2 & 1090 & 855 & 0,78 & 35,0 & $\mathrm{D}$ & 1016 & 0,93 & 31,0 & $\mathrm{E}$ \\
\hline 3133 & Jl. Trans Sulawesi 2 & 1090 & 427 & 0,39 & 45,0 & B & 545 & 0,50 & 45,0 & $\mathrm{C}$ \\
\hline 3141 & Jl. Trans Sulawesi 1 & 1227 & - & - & & - & 1283 & 1,05 & 34,4 & $\mathrm{~F}$ \\
\hline 3143 & Jl. Trans Sulawesi 1 & 1227 & - & - & & - & 1205 & 0,98 & 38,6 & $\mathrm{E}$ \\
\hline 3151 & Jl. Trans Sulawesi 1 & 1227 & - & - & & - & 1421 & 1,16 & 38,6 & $\mathrm{~F}$ \\
\hline 3153 & Jl. Trans Sulawesi 1 & 1292 & - & - & & - & 1198 & 0,93 & 34,5 & $\mathrm{E}$ \\
\hline
\end{tabular}

Sumber : hasil analisa

\section{Sirkulasi Arus Keluar Masuk Pelabuhan}

Berdasarkan matrik asal tujuan perjalanan, diketahui jumlah kendaraan yang menuju lokasi pelabuhan.

- $\quad$ Tingkat Kedatangan

- $\quad$ Tingkat Pelayanan rata-rata

- $\quad$ Tingkat Pelayanan

- Intensitas penggunaan

- $\quad$ Panjang antrian rata-rata :

$$
\frac{\rho^{2}}{1-\rho}=\frac{0,62^{2}}{1-0,62}=1,01 \text { kendaraan }
$$

Dari hasil perhitungan diatas bahwa pelayanan yang diberikan dengan menggunakan 1 (satu) loket bagi kendaraan yang akan masuk lokasi pelabuhan dengan tingkat kendaraan dalam sistem adalah 1,01 kendaraan, maka pintu loket yang disiapkan cukup satu pintu pelabuhan.

\section{Permasalahan Lalu Lintas}

Permasalahan terjadi pada 16 ruas jalan yang mengalami penurunan kinerja jalan menjadi tingkat pelayanan E dan 1 ruas dengan tingkat pelayanan D. Rendahnya kinerja jalan tersebut dikarenakan ruas jalan yang tersedia saat ini masih berupa ruas jalan tipe
: 288 Kendaraan

: 8 detik $(0,13$ menit $)$

: 60/0,13 = 462 kendaraan perjam

: $288 / 375=0,62$ 
2/2 UD yang tidak mampu untuk mempung volume lalu lintas dengan volume tinggi. Selain itu, Kabupaten Minahasa belum mempunyai pengaturan lalu lintas yang memadai.

Jumlah penumpang tiap keberangkatan kapal yang berjumlah 800 orang dan persentase penggunaan moda angkutan umum di Kabupaten Minahasa Selatan yang mencapai 39,2\% dan rata-rata okupansi kendaraan untuk angkutan umum adalah sebesar 8, maka diperkirakan akan ada 40 kendaraan umum yang menaik turunkan penumpang tiap waktu keberangkatan kapal. Kondisi eksisting sekitar lokasi pembangunan pelabuhan belum terdapat fasilitas - fasilitas yang bagi penumpang yang menggunakan kendaraan umum maupun bagi penumpang yang barjalan kaki. Hal ini akan menyebabkan ketidak teraturan lalu lintas pada sekitar lokasi pembangunan pelabuhan. Angkutan umum yang berhenti sembarangan dan pejalan kaki yang tidak disediakan fasilitas menyusuri maupun menyeberangi akan menyebabkan tambahan antrian lalu lintas di sekitar pelabuhan.

Belum tersedianya fasilitas parkir bagi kendaraan pengantar dan penjemput penumpang juga dapat menyebabkan gangguan lalu lintas. Ketidak tersediaan fasilitas parkir yang memadai akan menyebabkan munculnya permasalahan baru berupa parkir on street yang akan mengganggu kelancaran lalu lintas di sekitar pelabuhan.

\section{Penanganan 1}

Merupakan skenario peningkatan kinerja lalu lintas dengan melakukan peningkatan kapasitas jalan dengan menambah lebar jalan. Ruas jalan pada kondisi saat ini masih berupa tipe jalan 2/2 UD, sehingga untuk menambah kapasitas ruas jalan perlu dilakukan pelebaran dan penambahan ruas jalan. Usulan pemecahan ini dilakukan dengan meningkatkan ruas jalan dengan tipe 2/2 UD menjadi ruas jalan dengan tipe 4/2 D pada ruas Jalan Trans Sulawesi 1 dan Trans Sulawesi 2 selain itu pada penanganan ini juga diberlakukan jam khusus kendaraan berat yang memasuki Kabupaten Minahasa Selatan. Hasil pembebanan dengan menggunakan usulan penanganan 1 terdapat peningkatan kinerja lalu lintas pada ruas - ruas jalan yang bermasalah. Ruas jalan yang bermasalah mengalami peningkatan kinerja lalu lintas menjadi tingkat pelayanan A yang sebelumnya pada ruas jalan tersebut memiliki tingkat pelayanan E. 
Tabel 4 Peningkatan Kinerja Jalan Dengan Pengoprasian Penanganan 1

\begin{tabular}{|c|c|c|c|c|c|c|c|c|c|c|c|}
\hline \multirow{2}{*}{$\begin{array}{l}\text { Kode } \\
\text { Link }\end{array}$} & \multirow[b]{2}{*}{ Nama Jalan } & \multirow[b]{2}{*}{ Kapasitas } & \multicolumn{4}{|c|}{ Dengan Pembangunan } & \multirow[b]{2}{*}{ Kapasitas } & \multicolumn{4}{|c|}{ Dengan Skenario } \\
\hline & & & $\mathbf{V}$ & $\begin{array}{c}\text { V/C } \\
\text { Rasio } \\
\end{array}$ & $\mathbf{S}$ & Kinerja & & $\mathbf{V}$ & $\begin{array}{c}\text { V/C } \\
\text { Rasio } \\
\end{array}$ & $\mathbf{S}$ & Kinerja \\
\hline 3021 & J1. Trans Sulawesi 1 & 1292 & 1200 & 0,93 & 30,0 & $\mathrm{D}$ & 2733 & 544 & 0,20 & 42,0 & $\mathrm{~B}$ \\
\hline 3031 & Jl. Trans Sulawesi 1 & 1292 & 1266 & 0,98 & 32,0 & $\mathrm{E}$ & 2733 & 610 & 0,22 & 40,0 & $\mathrm{~B}$ \\
\hline 3033 & Jl. Trans Sulawesi 1 & 1305 & 1000 & 0,77 & 33,4 & $\mathrm{D}$ & 2614 & 465 & 0,18 & 40,2 & B \\
\hline 3043 & Jl. Trans Sulawesi 1 & 1266 & 1220 & 0,96 & 28,0 & $\mathrm{E}$ & 2733 & 576 & 0,21 & 45,1 & $\mathrm{~B}$ \\
\hline 3051 & Jl. Trans Sulawesi 1 & 1266 & 1184 & 0,94 & 30,0 & $\mathrm{D}$ & 2733 & 591 & 0,22 & 45,1 & $\mathrm{~B}$ \\
\hline 3053 & J1. Trans Sulawesi 1 & 1227 & 1160 & 0,95 & 28,1 & $\mathrm{E}$ & 2733 & 545 & 0,20 & 45,0 & B \\
\hline 3061 & Jl. Trans Sulawesi 1 & 1266 & 1278 & 1,01 & 28,1 & $\mathrm{~F}$ & 2733 & 638 & 0,23 & 45,0 & B \\
\hline 3063 & Jl. Trans Sulawesi 1 & 1227 & 1162 & 0,95 & 28,0 & $\mathrm{E}$ & 2733 & 546 & 0,20 & 45,6 & $\mathrm{~B}$ \\
\hline 3071 & Jl. Trans Sulawesi 1 & 1292 & 1275 & 0,99 & 30,4 & $\mathrm{E}$ & 2733 & 653 & 0,24 & 45,6 & $\mathrm{~B}$ \\
\hline 3073 & Jl. Trans Sulawesi 1 & 1226 & 1098 & 0,90 & 33,0 & $\mathrm{D}$ & 2733 & 543 & 0,20 & 45,3 & B \\
\hline 3111 & Jl. Trans Sulawesi 2 & 1090 & 1016 & 0,93 & 31,0 & $\mathrm{E}$ & 2733 & 467 & 0,17 & 45,0 & $\mathrm{~B}$ \\
\hline 3133 & J1. Trans Sulawesi 2 & 1090 & 545 & 0,50 & 45,0 & $\mathrm{C}$ & 2733 & 177 & 0,06 & 45,0 & $\mathrm{~B}$ \\
\hline 3141 & J1. Trans Sulawesi 1 & 1227 & 1283 & 1,05 & 34,4 & $\mathrm{~F}$ & 2733 & 638 & 0,23 & 45,6 & $\mathrm{~B}$ \\
\hline 3143 & Jl. Trans Sulawesi 1 & 1227 & 1205 & 0,98 & 38,6 & $\mathrm{E}$ & 2733 & 553 & 0,20 & 45,0 & B \\
\hline 3151 & Jl. Trans Sulawesi 1 & 1227 & 1421 & 1,16 & 38,6 & $\mathrm{~F}$ & 2733 & 729 & 0,27 & 45,0 & $\mathrm{~B}$ \\
\hline 3153 & Jl. Trans Sulawesi 1 & 1292 & 1198 & 0,93 & 34,5 & $\mathrm{E}$ & 2733 & 539 & 0,20 & 45,6 & $\mathrm{~B}$ \\
\hline
\end{tabular}

\section{Penanganan 2}

Pada usulan pemecahan masalah ini akan dibuat tempat perhentian bagi kendaraan umum yang akan menaik-turunkan penumpang yang menuju dan dari pelabuhan. Dengan perhitungan jumlah celukan menggunakan persamaan dibawah ini :

$$
N=\frac{P}{S} x \frac{(B \times S)+C}{3600}
$$

Dimana :

$\mathrm{N}=$ jumlah teluk bus

$\mathrm{P} \quad$ = jumlah penumpang maksimal yang menunggudi halte (orang/jam)

$\mathrm{S}=$ kapasitas angkutan umum (orang/kendaraan)

$\mathrm{B}=$ waktu pengisisan/boarding time (detik)

$\mathrm{C}$ = waktu pengosongan teluk bus/ clear

Maka jumlah telukan yang diperlukan dengan perkiraan jumlah penumpang yang akan menggunakan angkutan umum adalah sebanyak 314 orang untuk pelabuhan umum dan di dapatai hasil sebagai berikut :

$$
N=\frac{314}{8} \times \frac{(10 \times 8)+10}{3600}
$$

$=0,98125$ telukan 
Dengan demikian jumlah telukan yang diperlukan untuk mengangkut penumpang angkutan umum di pelabuhan umum berjumlah 1 telukan.

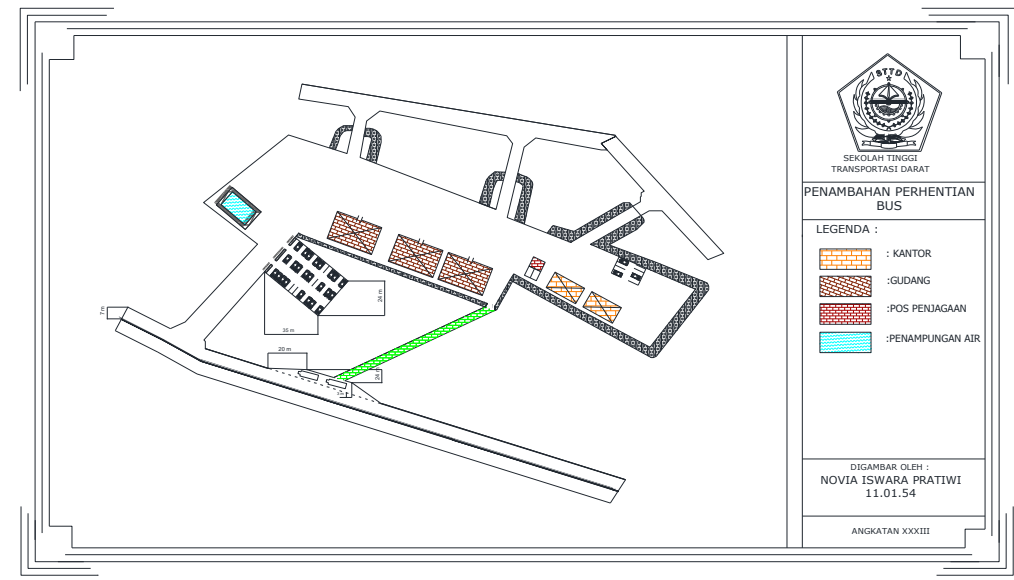

Gambar 1 Penanganan 2

\section{Penanganan 3}

Dengan nilai $\mathrm{N}$ sebagai lebar tambahan sesuai keadaan sebesar $1,5 \mathrm{~m}$, hal ini disebabkan karena menurut penulis pelabuhan menyebabkan bangkitan pejalan kaki dengan jumlah besar. Dari hasil perhitungan diketahui lebar minimal trotoar yang perlu disediakan adalah 1,67 m. Selain fasilitas berupa trotoar, diperlukan fasilitas penyebrangan yang dapat ditentukan jenisnya menggunakan perhitungan $\mathrm{PV}^{2}$.

$$
314 \times 797^{2}=199455626
$$

Hasil perhitunga tersebut menunjukkan bahwa nilai $\mathrm{PV}^{2}$ adalah $>10^{8}$. Sesuai dengan ketentuan, maka jenis fasilitas penyebrangan yang harus disediakan adalah Pelican.

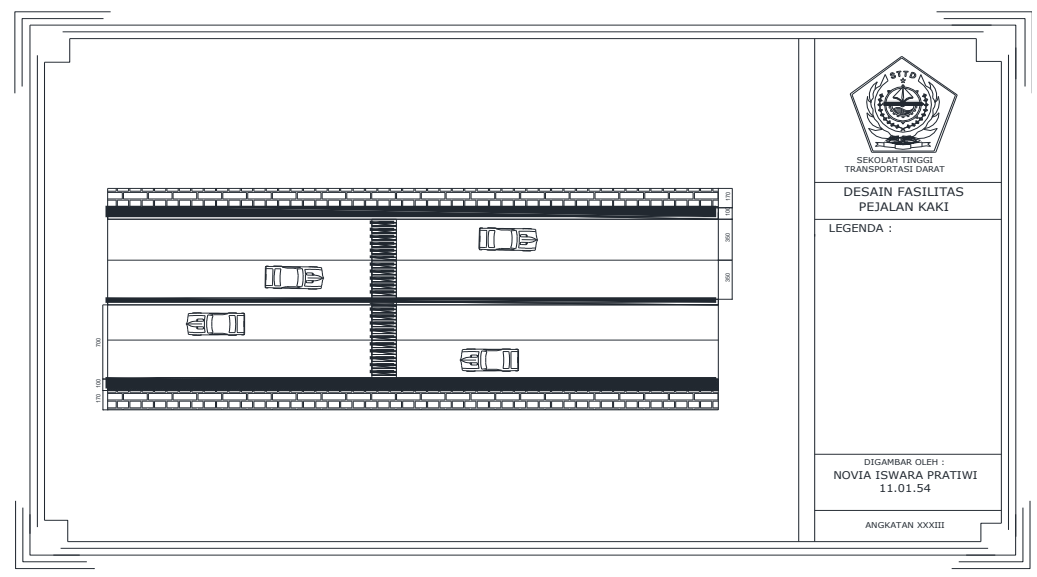

Gambar 2 Penanganan 3

\section{Penganan 4}


Usulan pemecahan masalah pada skenario ini adalah dengan penyediaan fasiliitas parkir. Adapun perkiraan Jumlah kendaraan yang akan pakir di pelabuhan adalah 30 kendaraan, untuk mengantisipasi jumlah kendaraan yang parkir lebih banyak dari fasilitas yang disediakan, maka jumlah parkir yang akan disediakan pada skenario ini mampu untuk menampung 50 kendaraan.

Tabel 5 Perhitungan Kebutuhan Luas Lahan Parkir

\begin{tabular}{cccccc}
\hline & & & & & \\
SUDUT & KAPASITAS & $\begin{array}{c}\text { LEBAR } \\
\text { KAKI }\end{array}$ & $\begin{array}{c}\text { RUANG } \\
\text { EFEKTIF }\end{array}$ & $\begin{array}{c}\text { INDEKS } \\
\text { PARKIR }\end{array}$ & $\begin{array}{c}\text { LUAS LAHAN } \\
\text { PARKIR (M2) }\end{array}$ \\
\hline 0 & 50 & 5 & 7,9 & 0,6 & 1185 \\
30 & 50 & 5 & 7,75 & 0,6 & 1162,5 \\
45 & 50 & 3,7 & 9,35 & 0,6 & 1037,85 \\
90 & 50 & 3 & 10,5 & 0,6 & 945 \\
\hline Sumber : Hasil Analisa & & 11,2 & 0,6 & 840 \\
\hline
\end{tabular}

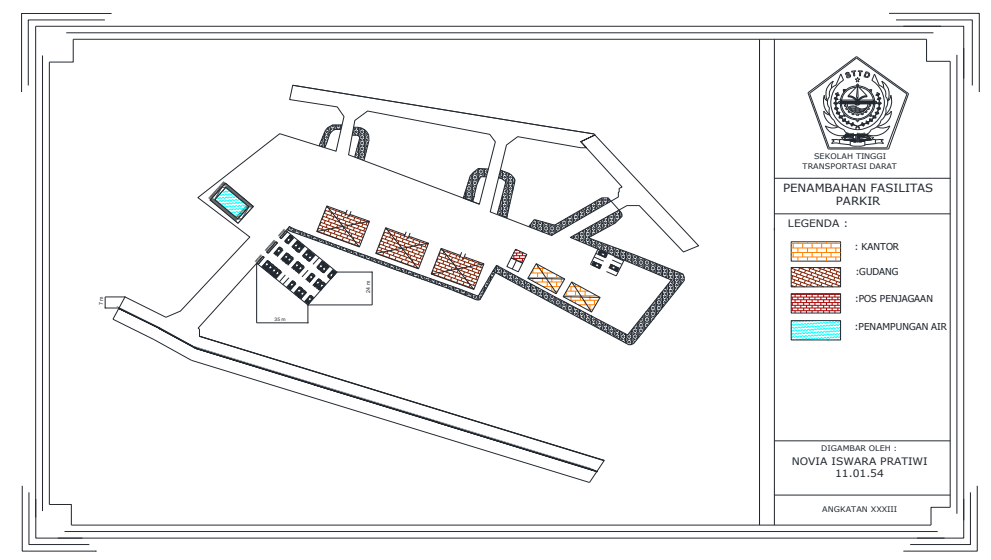

Gambar 3 Penanganan 4

\section{KESIMPULAN}

Adanya pengoprasian Pelabuhan Umum Mobongo membawa dampak pada kinerja lalu lintas di Kabupaten Minahasa Selatan berupa penurunan tingkat pelayanan. Penurunan kinerja terbesar pada tahun pengoprasian yaitu pada ruas jalan 3063 dan ruas jalan 3073 yang mengalami kenaikan v/c rasio sebesar 0,09 yaitu dari 0,53 menjadi 0,62 dan 0,49 menjadi 0.58. Dan pada 5 tahun pengoprasian diperkirakan ruas jalan yang akan mengalami penurunan kinerja lalu lintas terbesar adalah ruas jalan 3021 yaitu sebesar 0,33 dari 0,60 menjadi 0,93 . Terdapat beberapa usulan pemecahan masalah yang akan meningkatkan kinerja lalu lintas dan dari beberapa usulan pemecahan masalah, usulan pemecahan masalah skenario 1 yaitu dengan melakukan pelebaran dan penamabahan ruas jalan dan dengan adanya pengendalian waktu oprasional kendaraan barang atau kendaraan berat yang memasuki Kabupaten Minahasa Selatan terbukti menjadi skenario 
yang efektif meningkatkan tingkat pelayanan di ruas jalan Kabupaten Minahasa Selatan. Peningkatan perbesar pada skenario 3 yaitu pada ruas jalan 3081 dan 3151 yaitu sebesar 0,89 dari 1,12 menjadi 0,24 dan 1,16 menjadi 0,27 dengan tingkat pelayanan awal $\mathrm{F}$ menjadi tingkat pelayanan B.

\section{DAFTAR PUSTAKA}

1. Djamal, I dan Abimanyu, U, 1993, Pengaruh Pemanfaatan Gedung Tinggi Terhadap Dampak Lalu Lintas, Bahan Seminar Dampak Pemanfaatan Intensitas Lahan Gedung tinggi/Superblok di Jakarta terhadap Lalu Lintas di Sekitarnya, Universitas Taruma Negara Bekerja Sama Dengan Pemerintah DKI Jakarta.

2. Hidayat, Budi H. dan Mitra Nanda S, 2014, Analisis Dampak Lalu Lintas (Pengaruh Pembangunan Terhadap Lalu Lintas), Aura Pustaka, Yogyakarta.

3. Munawar, Ahmad, 2006, Manajemen Lalu Lintas Perkotaan, Beta Offset, Jogjakarta.

4. Triatmodjo, Bambang, 2007, Pelabuhan, Beta Offset, Yogyakarta.

5. Priyono Bejo, (2011), Analisis Dampak Lalu Lintas Rencana Penerapan Kawasan Chinese Square Kota Tanjungpinang, Skripsi pada Sekolah Tinggi Transportasi Darat: tidak diterbitkan.

6. Tamin, O.Z, 2000, Perencanaan dan Permodelan Transportasi, ITB, Bandung.

7. Warpani, Suwardjoko, 1990, Merencanakan Sistem Perangkutan, ITB, Bandung.

8. Qadri, M.A., (2003), Analisis Dampak Lalu Lintas Pembangunan Pelabuhan Terpadu Ulee Lheuhe Kota Banda Aceh, Skripsi pada Sekolah Tinggi Transportasi Darat: tidak diterbitkan. 